\title{
Professional self-employment, new power and the sharing economy: Some cautionary tales from Uber
}

\section{Patricia Leighton}

\begin{abstract}
This article reflects on some of the major changes in the ways that people are working today, changes often driven by a preference for greater autonomy and choice, but also to work on a sharing, collaborative or networked basis. Many of the growing numbers of independent professionals are attracted by these ways of working. Developments in Information and Communication Technology have been critical, especially in enabling services, including professional services, to be delivered via internet platforms. This has created, in effect, new forms of intermediation and increasingly complex work relationships. These developments have often proved very controversial, as instanced by the disputes surrounding Uber, the international, internet-based taxi provider. Many of these changes also raise issues of accountability and work quality, along with creating new patterns of work relationships. Inevitably, the changes also highlight the role of regulation, which is the main focus of this article The topic is explored against a backdrop of much recent deregulation, challenges to so-called 'red tape' and laissez faire policies. The myriad of disputes and litigation involving Uber is examined and reflected upon. There are, of course, many differences between the taxi drivers of Uber and the designers, journalists, engineers and consultants, typical of independent professional working, but there are also some key parallels and experiences that provide a cautionary tale!
\end{abstract}

Keywords: self-employment, collaboration, labour management issues, regulation

Received 24 February 2016. Accepted 27 August 2016

\section{INTRODUCTION AND OBJECTIVES}

$\mathrm{T}$ his article considers some ways of working that depart from traditional forms of work. Traditional work generally provides employee status and work relationships are typically tightly regulated by legislation, social dialogue and individual contracts (Leighton \& Wynn, 2011). Onto these relationships are grafted social rights and protections, including pensions, which are generally seen as part and parcel of what 'work' means. This notion of traditional employment has brought stability and predictability to the workplace. When things go wrong, there are procedures and institutions to help resolve them in most jurisdictions.

For a variety of reasons this picture is changing, with increasing numbers, especially knowledge workers, seeking the ability to determine their own working life (Institute of Public Policy Research, 2015) These are the independent self-employed professionals (IPros), whose numbers have grown by $45 \%$ across the EU in the last decade (Rapelli, 2012; Leighton, 2013; International Labour Office [ILO], 2016). IPros are typically well educated and skilled. They are of increasing importance to creative industries 
(Dellot, 2013), health care, education and wide range of professional occupations, such as engineering, journalism, translation, consultancy and to liberal/regulated professions such as lawyers and accountants (Rapelli, 2012; Solicitors Regulatory Authority and the Legal Services Board [SRA/LSB], 2015).

Employing organisations, too, are changing. Many see the value of using independent, more flexible and agile workers (Burke, 2012; Ackers, 2014). Despite growth and evidence of emerging recognition by legislators and policy-makers (Cooper, 2006; European Commission [EC], 2012, 2014), people working for themselves but not aiming to employ others often find themselves as 'outsiders' and hard to define. They are not clearly within the small and medium enterprises (SMEs)/entrepreneurship community, or unambiguously subject to labour market provisions (Leighton, 2011). Questions of definition and categorisation have therefore proved problematic for this group.

There are many drivers of change, though a desire for personal autonomy features strongly (Mckeown, 2009-2015; Gratton, 2011; PriceWaterhouseCoopers [PWC], 2016). However, probably it has been the opportunities provided by Information and Communication Technology (ICT) and internet platforms that has had major impact (Pelissie du Rausas, 2015; Carbonaro, 2016). This has enabled various forms of intermediation being used to bring skills/facilities providers and seekers together, and the development of new ways of providing services (European Foundation (EF), 2015; NESTA, 2015). Uber, the taxi service, is perhaps the best known of these internet-based service providers, although there are growing numbers and variety in services being provided this way and we seem to be in the midst of creating a complex and fast moving picture of service delivery. Just as the issue of being nontraditional creates challenges for individuals who work for themselves, technology is rapidly challenging the ways that work is accessed and undertaken and, importantly, presents major challenges for the nature and effectiveness of work relationships (Leighton \& Mckeown, 2015).

These new ways of working and service delivery, often referred to as the 'gig' or 'digital' economy are typically unregulated or only very lightly regulated (Marchington, Grimshaw, Rubery, \& Willmot, 2004; Friedman, 2014). As such, they are raising a range of issues, especially legal ones, from consumer protection, through to accountability and liability. This is leading some to ask whether and how these new ways of working should be better controlled. Many of these 'control' issues are already familiar to analysts of the world of the IPros and their ways of working. This because of the sometimes uneasy relationship or even major disputes between liberal/regulated professionals and those, often engaged in similar work, that are less or unregulated. It is often argued that regulation of professional work is simply disguised protectionism and the prevention of competition which, in turn, inhibits innovation and efficiency. Those who are subject to regulation generally reject this, instancing the long period of training and lifelong learning that many liberal/traditional professionals are subject to (Kenny, 2014; SRA/LSB, 2015).

It is suspected that more complex work patterns and means of service delivery can only generate even more debates and uncertainties (Stone \& Arthurs, 2013) However exciting, novel and attractive some of these ways of working are, there is an imperative to have a long hard look at them and ask some basic legal and practical questions (Ghosh \& Malloy, 2011). The fact that labels such as 'innovative', 'collaborative' and 'sharing' are attached to various ways of working cannot lessen the imperative to question. It is argued that the most basic and urgent question is that of the role, nature and relevance of regulation (Campbell, 2010; Coopman, Mitchell, \& Thierer, 2014). The current mantra of governments, businesses and policymakers has been to call for deregulation and the removal of so-called 'red tape'. They argue that innovation and creativity are stifled by regulation, that individuals and businesses thrive in regulation-free environments and, anyway, the market and consumers will safeguard proper standards and quality in service delivery.

\section{THE AIMS OF THIS ARTICLE}

This article aims to reflect on these changing work practices, drawing on relevant research, including interviews and case studies, as yet unpublished, undertaken by the author of this article. In efforts to 
suggest appropriate frameworks and policies for successful IPro working, the controversies, conflicts and litigation, especially concerning Uber, are reviewed (EF, 2016). It is argued that allowing work practices to operate entirely freely, however much that may generate competition, innovation and disruption, may be ill-advised. In the interests of supporting independent working and establishing ways to sustain it, appropriate frameworks need to be established to maintain and enhance work experiences (Carbonaro, 2016), but also to protect consumers and support efficiency.

\section{NEW IDEAS AND NEW POWER}

Sometimes a theory, the findings of a research project or an initiative captures the imagination not just of academics but of policy-makers, the media and the general public. Recently, and perhaps in part as a dimension of emerging from the 2007 global recession, imaginations have been captured by notions of a new sharing and collaborative economy. The professional self-employed IPros, are especially attracted by working on a collaborative basis, as it is they who are increasingly populating coworking spaces, setting up cooperatives, creating new networks and working on an associative rather than employment contract basis. Developments in ICT have clearly made working collaboratively, along with working cross-border and working in more flexible ways both feasible and attractive.

A trigger for the interest and excitement about what can be seen as a radical critique of current business practices and work relations was an article published in December 2014, though others had written about the topic previously (see e.g., Gratton, 2011; Mettler \& Williams, 2011). In the article, Heimans and Timms (2014) argued that 'new power' is set to challenge or even replace 'old power' regarding the ways that businesses are conducted. This would be especially in terms of their relations with consumers, and how products and services are delivered but also how skills are accessed. A particular target for the article's authors are large and dominant multinational companies which are characterised by being hierarchical, formal, secretive, leader driven with top down decision-making processes, which are also typically unresponsive to external interests and are aggressively competitive. Several major multinationals, such as Apple, Walmart and Nike, despite being brand leaders, are generally considered 'old power'.

'New power organisations', according to Heimans and Timms (2014), are characterised by being participatory, peer driven/flat, open, innovative and forward-looking and have values based on sharing and collaboration. They suggest that Wikipedia, YouTube, Wefunder, the Alpha Course and the providers of other platforms that link service providers with customers are key examples. These include Airbnb, VRB, Lyft, Kabbee. However, they devote considerable time to the taxi firm Uber as perhaps the 'classic' example of new power. Uber uses sophisticated software to enable potential taxi passengers who have a particular app on their mobile phone to contact the company (Roy Morgan, 2016a), explain where they are and want to go and they usually pay Uber in advance by credit or debit card. In effect, the platform acts as an intermediary, linking individuals with the services they want to access. The promotional literature of Uber stresses that the people involved have an informal relationship and that Uber is merely 'carsharing' (Chokkattu, 2014). This model is used for a variety of services, including holiday accommodation, and a range of technical services. In principle, many high skill, professional services are capable of being provided through internet platforms, which is why the development is so important and merits close scrutiny (Green \& Barnes, 2013).

Of course, many of these service providers, such as drivers, delivery workers, cleaners and caterers recruited through internet platforms are very different from the knowledge workers typical of IPro working. However, it is argued that not only can the 'Uber/new power model' be applied to the provision of a wide range of services, including quite sophisticated ones, but that there is anyway much similarity between the Uber issues and some that confront many IPros. Not least here is the suspicion 
or even hostility that many that 'break the mould' face, but also many practical and legal issues (Leighton, 2014).

\section{A NEW PHILOSOPHY?}

Supporters of new power, mainly expressing their views in social media, also argue that the emerging business models are not just new ways of working but represent a new work philosophy. In part, this is explained by people wanting more control, increased autonomy and choice (Genov, 2014; Mckeown, 2000) but also perhaps a reaction to so many Old Power businesses, especially multinationals, that have run foul of the law, public opinion or both. Examples are not hard to find, with some organisations exploiting their workforces, for example, by using child labour and constantly seeking manufacturers and service providers in low cost, less-regulated economies (ILO, 2016). Others have been accused of tax avoidance, unfair business practices, environmental abuses and corruption (included here are Google, Starbucks, Shell and British Aerospace).

To an extent, then, 'new power' may be a reaction against excesses, especially by multinationals. In fairness, the Old Power critique can be equally applied to many trade unions, charities, the public sector and even international governance (Richardson, Kakabdse, \& Kakabadse, 2011). However, two questions now pose themselves, if new power is here to stay. First, how significant are these developments and what do they represent? In effect, how popular are these new power models and to what extent do their business practices mark a real change? Second, and most importantly, what challenges do they pose for existing institutions, regulation, social provisions and business and other practices? (Carbonaro, 2016). The second question is, of course, the one to which most of this article is devoted.

\section{HOW SIGNIFICANT ARE THESE DEVELOPMENTS?}

It is clear that in many ways, self-employment and autonomous forms of working that have been gathering momentum since around 2000 sit easily with new power (Mettler \& Williams, 2011). Although there are some differences, both reject hierarchies, top down decision-making, and control and both seek openness, collaboration and 'horizontal' ways of working. Indeed, research suggests that although the idea of being be your own boss and creating your own work relationships has great attraction (Mckeown, 2009-2015; EF, 2014), a sense of alienation from traditional (Old Power) organisation and being subject to what seems an increasingly rigorous Human Resource Management (HRM), is an important factor (Leighton, Syrett, Hecker, \& Holland, 2007; Leighton, 2013, 2015; Leighton \& Mckeown, 2015).

It is important to note that the rise of professional self-employment, along with collaborative and networked ways of working should not be seen as a mere extension of flexible working, which has also shown recent growth. There are more people now working at or from home, working part time or on, say, annualised hours contracts. Flexible working, which in essence is working other than as a full-time employee on a standard contract, simply represents work patterns which are a 'derogation' or a waiver provided by the employer to enable greater flexibility. This is often to accommodate caring or other demands but it is generally assumed by managers that once these needs have declined or ceased the employee will return to 'normal' working! In other words, flexible working can be seen as a concession from the normality of fulltime, workplace-based employment and we know that those who benefit from the 'concession' often make real sacrifices in terms of pay and careers (Lewis, 1997; Perlow \& Kelly, 2014). Indeed, it is possible that these sacrifices are one of the drivers of growth in independent/ IPro working, whereby those who seek flexibility, choice and work-life balance see value in independence, rather than having to compromise, as they see it, their careers for retention of their apparent security and employee status. 
The changes under consideration here are a far more radical development. Perhaps, the only parallel we can find are the changes brought about by the industrial revolution from the 18th century, whereby prior to industrialisation most people worked independently or collaborated through guilds or other structures After the industrial revolution, most became employees in increasingly large organisations. This situation then evolved into scientific management, such as Taylorism and other work forms that aimed to directly match employees to the employer's business needs (Giddens, 1991). Many argue that this development has led to increased casual and other forms of intermittent work, such as zero hours contracts and agency working, developments which many have long viewed with concern (Marchington et al., 2004). Others, including Bridge (2010), in this volume, argue that the growth in independent though sometimes more unstable forms of work is a return the 'typical' work', with employee status being the aberration rather than the norm.

But how real is this autonomy, sharing and collaboration? Is it just a passing phase or is something more profound occurring? Clearly, this is a difficult question and data remain limited. However, we know that the numbers employed by Uber worldwide are massive and growing, with other taxi firms using the same or similar business models arriving on the scene. We can easily access marketing and business information about some of the brand leaders in this way of working and can conclude that these are significant businesses that are capturing important markets (PWC, 2016). We also know that many knowledge workers, especially in the growth areas of health care, education and business services access work in this way (Leighton, 2013).

\section{UBER}

We need to turn now to turn attention to Uber, the taxi facilitator that has caused most controversy but has probably had greatest impact. Uber was set up in the United States in 2009. It is thought that it operates in at least 64 countries (though it is banned in some), in 78 capital cities, employs at least 1.1 million drivers aiming for 42,000 drivers in London alone, and has been recently valued at over $\$ 50$ billion (Chokkattu, 2014; Roy Morgan, 2016b). It operates out of the Netherlands and is covered by Dutch law. There are other taxi organisations using a similar business and internetbased model, such as Lyft and Kabbee and more recent rivals who are using similar technology-based business methods. As we shall see, the rise of this way of working has proved very controversial with a liturgy of court cases, industrial disputes, public disorder and complaints. Existing service providers' livelihoods are often threatened, a factor leading to increasingly vitriolic outcomes (Hill, 2015).

The way Uber works, as described above, appears easy to access, is allegedly cheaper than other taxi systems, and Uber drivers use newer and well-maintained cars. Uber reports that its drivers are screened by them, treated as self-employed (as 'partners') and are paid directly by Uber, usually some 8 days after money has been earned. Uber operates a customer satisfaction feedback system. If a rating is poor or there are specific complaints they can lead to deductions from pay by Uber or 'discontinuation' of the arrangement.

The rhetoric of sharing has proved powerful, with many arguing that Uber is simply a carsharing idea that works to the mutual benefit of car owner and passenger, and in the case of Airbnb, it is simply inviting someone to stay in your house when you have spare rooms. However, neither business is informal or charitable. Both are traditional companies using the business methods of a large multinational, with shareholders and a profit motive. Nonetheless, the romance of sharing has been a powerful magnet for both service providers and the users.

What about the actual service providers/drivers themselves? Despite the quite rigorous controls put in place by Uber especially in terms of seeking customer feedback, their drivers are treated as 
self-employed. In return for the benefits of accessing work through the internet platform, the drivers pay at least $25 \%$ of their earnings to Uber. Uber is not standing still and is increasing its market, developing new facilities such as carpooling and investing in driverless cars.

Providing a transport service is nothing new and Uber has many rival systems to compete with beyond those using internet platforms. These are the traditional tightly regulated 'black', 'yellow' and other cabs, along with in some countries registered 'mini' cab services which use different business models. As is considered more fully below, drivers of these types of taxis argue that competition from Uber is unfair as Uber drivers are not subjected to the regulations affecting many aspects of providing a traditional taxi service. Included here are training demands, specialist driving licenses, requirements for insurance and in many cases strict rules of conduct.

The extent to which Uber and other internet platforms facilitate genuine 'sharing' is a matter for debate. Adherents point to the rise of eBay and other ways of passing on goods and 'house sharing' via Airbnb as creating new notions of markets and economies. Cynics note the huge profits generated by these platforms and see 'sharing' as simply another capitalist device, coupled with advanced marketing (The Guardian, 2015; Hill, 2015).

Collaborative working, but perhaps not so much 'sharing' is also, as has been referred to above, a feature of much IPro working. They have long used platforms such as LinkedIn and specialist platforms for particular professions. They make considerable and growing use of coworking spaces (Spreitzer, Bacavice, \& Garrett, 205) and cooperatives. There is emerging evidence of innovative and collaborative working even amongst traditional regulated professions (compare the way professionals were working a few decades ago from Carr-Saunders \& Wilson [1933] and Abbott [1988] with data on the legal profession in Leighton [2013] and SRA/LSB [2015]).

A particular issue which cynics are beginning to highlight is the earnings of so-called 'gig' or 'crowd' workers of varying sorts of which Uber is but one example. Huws and Joyce (2016) undertook a survey of over 2,000 such UK workers, including, taxi drivers but also people working in occupations typical of IPro working. These include the creative industries, writing of various sorts, and health and other professional services who also found work through internet platforms such as Upwork and Handy. Interestingly, the authors of the research estimate over 5 million in the UK work this way (around 17\% of the total labour market), with over half (54\%) women, $57 \%$ doing professional work and over $60 \%$ creative work and $46 \%$ engaged in taxi work. Many in the sample had more than one role, and/or worked part time and the largest numbers came from English cities but only $10 \%$ were students. Some $43 \%$ had an annual income of below $£ 20 \mathrm{k}$, despite the fact that many were main earners; only $7 \%$ had earnings over $£ 55 \mathrm{k}$.

This research chimes with research which has been done on Uber drivers themselves (Pofeld, 2016). This found that although there were some high levels of satisfaction with working for Uber, this was not marked where the driver was fulltime but was confined to those driving as a second job or working part time. In other words, drivers dependent on Uber for their main or sole income were the most likely to voice complaints.

Concerns about earnings which some internet platforms facilitate but which can also lead to a 'race to the bottom' for pay is but one of the issues that has led to disputes. It is these disputes that provide the cautionary tales for IPros and the self-employed more generally.

\section{UBER: CONTROVERSIES, DISPUTES AND LITIGATION}

Such is the profile of Uber that an increasing number of business commentators, rather than academic writers have begun to catalogue the disputes (e.g., EF, 2016; Roy Morgan, 2016a). There are few countries in which Uber operates that have not experienced disputes. 
There tend to be three major themes which characterise these disputes. First and probably most importantly, there is the fundamental question of 'What, precisely, is Uber'? Things have come to head in the EU with the referral by a Spanish Court to the European Court of Justice (ECJ) ${ }^{1}$ of the question of whether Uber is simply an internet services provider or a public transport company? If the former, law has only limited ability to control its activities; if the latter, there are many laws both from the EU itself as well as national and local government that can be applied to Uber. However, disputes and litigation are by no means confined to Europe. Indeed, there are few jurisdictions where litigation has not featured.

The definitional conundrums generated by Uber are clearly also an issue for IPro working? The question can be simply posed. What is an IPro? An entrepreneur? A 'nano business'? A contractor? A specialist with labour markets? 'Not an employee'? This matter will be returned to.

The second theme combines regulation with the private law of contracts and it concerns the legal position of Uber drivers. What is their legal relationship with Uber? Are they genuinely self-employed or, in part hiding behind the rhetoric of sharing? Are they, in legal reality, employees of Uber and therefore in so-called 'sham' relationships (Muehlberger, 2007). Employment status is a global issue with courts struggling in most jurisdictions to differentiate the genuine self-employed from the employee. For example, we have recent case law from Australia that has summed up the issues effectively for the 'sharing economy' (de Flamingh and Cameron, 2015).

This issue also has relevance for access to social protections, taxation and even the application of areas of law, such as competition law ${ }^{2}$. It is also an area which has been and continues to be a running sore for supporters of IPro working with fiscal authorities in many jurisdictions constantly seeking ways to assert that many IPros are, in reality, employees and tax dodgers (e.g., from the United Kingdom, Office of Tax Simplification, 2014, 2015 and the Netherlands ${ }^{3}$ ).

The third area, and one that is less debated, concerns public safety and security and especially the role of regulation. The calls for deregulation, open competition and lifting burdens on business have gone virtually unchallenged in recent years in developed economies. We have therefore deregulated and have very little new regulation. The incidents and litigation concerning Uber has highlighted some of the risks that such policies can lead to. These include injuries in road accidents, assaults and threats, the lack of insurance and indemnity provisions, poor driving and navigation standards and general questions of 'What happens when it all goes wrong'?

Again, although the controversial issues of IPro working tend to be less dramatic, there can be concerns that an unregulated or lightly regulated provision of professional services can lead to lower standards and the possible decline of notions of 'professionalism' itself.

\section{THEME 1: WHAT EXACTLY IS UBER?}

To answer this at least for EU purposes, will have to await the decision of the ECJ on the Spanish case referred to above but it is key issue in many other jurisdictions. The ECJ decision is unlikely to be made before the end of 2016. In the meantime, a series of cases across EU member states have been dealing with the defining and categorising of Uber (EF, 2016). In litigation, Uber has often styled itself as a 'connecting service based on electronic mediation between people who want to share cars'. Although in a few cases this argument has prevailed, mostly it has not, with decisions in, say, Finland,

Associacion Professional Elite Taxis C-434/15: A case from the Netherlands decided by the ECJ.

ENV Kunsten Informatie (2015) C-413/13.

3 The Dutch Government has introduced legislation changes affecting IPros. They were scheduled to take effect on 1 May 2016 and are designed to provide for more control over the 'genuineness' of IPro self-employment and part of the new regime is the availability of model contracts from the tax authorities. 
Sweden and Italy deciding that Uber was a taxi service and subject to relevant rules. In Hungary, a 2015 Decree $^{4}$ restated the rules covering taxi services, now including 'car passenger services' taken to cover Uber. The Decree was challenged by Uber and has led to complaints by other taxi drivers that it has not been enforced. It seems little will be resolved until the ECJ lays down its decision.

Meanwhile, disputes rage outside the EU. They include disputes in the United States (Forbes, 2015; FT, 2016); India (Times of India, 2014); Kenya (Citizen Business, 2016) and Australia.

In trying to define and locate Uber for a range of legal and other reasons, there may be another way to look at Uber. This is as an intermediary in a context where intermediation, typically by employment agencies, is both defined and regulated in many jurisdictions (agency working is especially well developed in the United States, Japan, the United Kingdom and several Western EU states). The main intention of regulation has been protection of the 'temps' and prevention of exploitation (Busby $\&$ Christie, 2005), rather than of defining agencies, though there are exceptions ${ }^{5}$. At EU level we have the 2008 Temporary Agency Work Directive and although it is primarily also concerned with worker rights, it does contain some helpful definitions that could be applied to Uber. However, although this area of regulation could have relevance to Uber, we still have some major problems. First, the intermediary is an internet platform and hard to regulate, though it might be argued that the people who work in the many administrative offices of Uber could be seen as the 'real' intermediaries, as they make the key decisions affecting the work of individual drivers? But second, intermediation sets up so-called 'triangular' relationships whereby although there is a legal relationship between the intermediary (Uber) and the individual (driver), there is generally in most legal jurisdictions no legal relationship between the client - here the passenger - and driver.

Questions of definition and categorisation are also key issues for IPros. As referred to above, the fundamental question is whether they are part of the business community, in effect being nanobusinesses/solopreneurs and the like? If they are not, is it appropriate that they are regulated by business provisions? Or, are they simply a specialist part of the labour market, being the highly skilled self-employed? In which case, are they appropriately covered by labour/employment law (Leighton, 2011). Definitional issues around IPro working are typically generated by fiscal authorities, arguing that self-employed status is a 'sham' or by the apparent self-employed themselves seeking employment protective rights. Cases might arise out of areas of law such as equality, health and safety and human rights.

These are major questions that merit more exploration and debate (Kitching \& Smallbone, 2012; Stone \& Arthurs, 2013; Coopman, Mitchell, \& Thierer, 2014).

\section{THEME 2: WORK RELATIONSHIPS}

The regulation of the workplace is self-evidently geared to traditional employment, largely based on employee status and until recently, full-time employment. The key players have been employers and in most developed economies, trade unions, such that employment terms and conditions of work have been generally arranged through collective bargaining and agreements, leaving a relatively minor role for the state and national legislation. So strongly embedded have been these features (though weaker in common law jurisdictions such as the United States and United Kingdom), that even the growth in part-time working and other forms of flexible work, such as job sharing and homeworking have often faced resistance. The rise of employment agencies and other forms of intermediation have also

4 Hungarian Government Decree 176.2015 (V11.7.).

5 Conduct of Employment Agencies and Businesses Regulations in the UK from 1976 onwards, require registration, transparent work systems, financial probity and fair practices, especially for temps. 
provoked hostility, with agencies being illegal in some states until recently (Heery et al., 2004; Busby \& Christie, 2005; Heery, 2005).

Change has not been easy and the self-employed have often been at the forefront of controversy and challenge. In terms of Uber, the key question has been what, exactly, is the legal relationship between Uber drivers and Uber? The fact that services are provided on an attractive, innovative and allegedly shared basis does not alter this underlying need to analyse the relationship, not least because the implications of a particular employment status go beyond the workplace. They touch on matters of accessing loans and mortgages, social protections and provision for retirement, as well as issues directly related to employment.

An important issue and one already touched on is the question of 'sham'/'disguised'/'false'/or even 'fraudulent employment contracts' (Casale, 2012), which, as mentioned above has also been such an issue for many IPros. The argument is that is that describing Uber drivers as 'partners' is merely a device to disguise their 'true' employee status.

This is a long running, unresolved issue in most jurisdictions (Leighton \& Wynn, 2011; European Forum for Independent Professionals [EFIP], 2015), where different tests are applied in different states, at different times and with differing consequences when trying to differentiate the genuine selfemployed from employees. Attempts have been made to explore various aspects of the employment relationship as providing the essential key to its nature. For example, Is the individual in question sufficiently 'subordinate' to the employer? Are they integrated into the employer/client business? Do they lack the features that a genuine entrepreneur would have, such as providing their own facilities and equipment, having a range of clients and, today, having a website, being Value Added Tax (VAT) registered and using an accountant? This might suggest employee status.

Unsurprisingly, the advent of the digital platform and assertions that we are moving into an entirely new era of the world of working have inevitably made these tasks more difficult, compounded by the fact in Uber's case that the contractual documents they use are designed to inhibit legal challenges, though they cannot prevent it.

The global Uber case law is of interest because the notion of sharing appears to have little impact or relevance when tests of employment status are being applied. The key questions have tended to concern the control which Uber exercises, or does not, over the drivers. Those who argue they are properly employees point to the apparently strict selection and screening rules before they can join. There is, then, the feedback process from passengers, other rules of conduct, the supply of the smart phones to drivers, incentive payments based on productivity and, importantly, assurances given to drivers of intervention by Uber if drivers face problems. Hopefully, the myriad of cases before courts in this question will clarify the nature of the employment relationship between Uber and its drivers, though one fears that confusions and anomalies will likely continue.

However, the relational and definitional issues go wider and are critical for policy and law-making. Are people providing services, especially perhaps the homeowners in Airbnb, also nano-businesses? (and is there a business relationship between the owners and 'house guests'?). Could the Uber drivers, who in theory are free to 'partner' with other organisations also be nano-businesses? Do the elements of choice, opportunity, sharing and collaboration add a dimension on how we define people at work? In a borderless, digital world, are they more likely to be seen as self-employed?

We simply do not know, as cases, at least those concerning Uber drivers, have varied from state to state in the United States, as between EU states and in Australia. All we are learning is that the Uber cases have highlighted what has been a running sore of labour markets across the world. This is the failure to clearly differentiate the two groups, or, and this is hugely important, reconsider why we have the two groups at all and whether an inclusive or different system could be put in place. It is thought that the EU at least is aiming to do this, but it is likely to be a very difficult task (EFIP, 2015). 
There are other legal reasons why locating both Uber drivers and many IPros into the 'right' category is important. These are to do with commercial considerations. These hinge on the distinction between commercial relationships which are covered by specialist jurisprudence, such as competition law and corporate law, and genuine employment relationships covered by employment/labour law (Drexl \& Di Porto, 2015). The application of one area of commercial law-competition law, within the EU has provided some interesting insights into the question of categorising work relationships. Commercial organisations are covered by the increasingly important competition law; employees are not.

Early competition case law suggested that if a person was under the 'direction' of another they were not a commercial entity and outside the law, for example, for the purposes of analysing the effects of collective agreements and restrictive labour practice. In a recent case, involving freelance substitute orchestra musicians it was for the ECJ to determine whether the fixing of fees for the work was anticompetitive. It was held by the ECJ that if the musicians were 'falsely' self-employed (i.e., really employees) they were outside the scope of competition law but if genuinely self-employed they were covered. The court rejected the Advocate General's advice that a wider approach be taken and recognise the often subtle pressures on individuals to comply with the 'norm' - whatever it might be. Here, the label of self-employment was held to be accurate, so competition laws could apply. This often neglected case law is a rich source of insights into this notoriously difficult area of employment relationships, and also has important implications for both Uber and competitive market places, but also for many IPros, especially perhaps those using limited companies.

\section{THEME 3:THE ROLE OF REGULATION}

This is the crucial issue. As touched on earlier, in recent years it has become fashionable to describe regulation as 'red tape' and to see it as inhibiting innovation, development and competitiveness. 'Deregulation' has become a clarion call not just in the common law world but within the EU and wider. Particular concerns have been voiced on the need to ensure small businesses are not overburdened and unable to thrive (Ghosh \& Malloy, 2011). Hence, there have been measures in many states to ensure the setting up a business, accessing finance, dealing with bureaucracies and fiscal bodies is simplified. And yet there has been very little debate or research on the effects of regulation itself (Campbell, 2010).

Many of the reports, disputes and litigation regarding Uber's business practices concern whether and to what extent they are or should be regulated. We have reports of fatalities caused by the driving of Uber drivers, perhaps the most widely reported was that of Syed Muzaffer who killed a 6-year-old child in the United States. He was allegedly not concentrating on driving as he was checking his phone. A claim made against Uber, on the basis of its vicarious liability was rejected but subsequently quietly settled out of court, though Uber continued to deny responsibility (ABC News, 2014). There have been also alleged sexual and other attacks on passengers, racist and homophobic behaviour, refusals to give lifts to disabled people, all of which can lead to a ban on providing a taxi service where the service is regulated. The role of the law of contract is also a key regulatory issue. Uber's contracts are governed by Dutch law and require arbitration before litigation, both, it appears requiring litigants to go to the Netherlands! This is an effective deterrent. With global reach, use of internet platforms and with organisations able to choose the 'best' legal jurisdiction for their purposes, the issue of the effective enforcement of regulatory provisions needs urgent attention.

There are then linked matters of insurance, training and supervision again, typically required by regulated taxi businesses. It is argued that the greater the complexity and uncertainty about new ways of providing services, the greater the need to consider this basic issue. Although, the issues around Uber

6 ENV Kunsten Informatie (2015) C-413/13. 
have been highlighted where the people involved are less skilled and qualified than the knowledge workers typical of IPro working, these issues and examples do seem, potentially, to have great relevance for IPros.

There are, of course, many wider concerns about the medium to longer term effect of new business and work models which are beyond the scope of this article. Mostly, these focus on labour markets, employment relations (Dygryse, 2016) and social protections (Pofeld, 2016). At present, policy and lawmakers are adopting a generally cautious approach to these concerns and seeking further research data. However, there can be no doubt that, increasingly, the issues are seen as serious and meriting attention.

\section{SUMMARY}

What can we learn of relevance from Uber, especially in terms of other independent and new forms of work? Analysis is undertaken from two perspectives.

First, a $360^{\circ}$ look at Uber, focussing on the main 'stakeholders'. These are as follows:

- Uber passengers;

- Uber drivers;

- Non-Uber drivers;

- Uber itself.

This is not to overlook other and important stakeholders - such as members of the public who might also be affected by Uber activities.

\section{Uber passengers}

They are the direct clients of the Uber experience. Let us sum up the problem areas and ambiguities.

- There is no contract between the passenger and the driver. Passengers contract with Uber. If there are problems and disagreements, as Uber treats the drivers as self-employed they will deny vicarious liability for a driver who causes harm.

- There is no obvious means of redress for passengers if things go wrong (some have been attacked, abused and robbed), as there is not usually a regulatory body that is responsible for standards. Only Uber can take action against drivers.

- Passengers anyway have problems in enforcing claims through local or accessible courts.

- The rhetoric of sharing has meant that, in most jurisdictions, drivers are not required by Uber to have a special driving license, special insurance, etc. or undertake appropriate training. Nonetheless, they are subject to a strict set of rules which enables Uber to terminate an arrangement they have with a driver, though it is thought that the motivation for this is to protect Uber's reputation rather than public safety, etc.

- The issue of training and skills has proved very contentious and resonates closely with aspects of IPro working. Some argue that the lack of training means that drivers sometimes get lost, take longer routes than necessary and cannot deal with emergencies.

\section{Uber drivers}

- Interviews with them suggest they have mixed responses to their work, though the most satisfied are those working part time or as a second job. This gives them extra cash but also flexibility (Pofeld, 2016). My own interviews tend to confirm this.

- They are at personal risk if they have an accident or otherwise cause harm (for which they are individually responsible), or themselves suffer loss. Insurance costs are extremely high. 
- The major regulatory issue is that of employment status, with Uber declaring them to be selfemployed, but courts sometimes finding them to be, in reality, employees of Uber.

- This lack of protection, according to some commentators (European Parliament Magazine, 2015) makes them especially vulnerable. Many argue that Uber creates what he calls 'dead end jobs' which lead to a 'servitude bubble'. So, what can start off as ambitious, contemporary and value-driven developments, might well, even in the medium term have major downsides.

\section{Non-Uber drivers}

They have been vocal in their opposition to Uber in many states. They have literally taken to the streets, launched legal claims, lobbied strongly and have generally argued for curbs on Uber. The issues that affect them are as follows:

- They consider that they are subject to unfair competition, not least through the costs of their complying with regulations, training costs, etc.

- Challenging the current situation has proved difficult, with state bodies, declaring themselves to be antiprotectionist, often rejecting their claims in the interests of increased competition, so as to improve choice, reduce costs and encourage innovation.

- They also fear reduced incomes not least because Uber is increasing its driver numbers dramatically, putting more strain on incomes. To become a Black Cab driver in London, for example, takes up to 4 years preparing for a test called The Knowledge relating to London roads, facilities and requires drivers to be aware of roadworks, congestion, etc. and to know the 'best' routes. As well as the costs associated with this, the taxis themselves cost upwards of $£ 40 \mathrm{k}$, and the drivers are part of a specialist regulatory system that sets fares, requires response to the first person wanting a cab and applies strict rules to conduct and driving.

\section{Uber}

Uber, along with other internet-based service providers, has clearly developed and is evolving a brilliant idea. It makes service provision easy and direct and their service provision is underpinned by major investment in technology. However

- Despite the technological innovation and specialist business model Uber itself is rather old fashioned. It is a traditional, hierarchical company, dependent on shareholder approval and priorities.

- Uber is facing one core challenge. This how, if at all, it is to be regulated? The case before the ECJ for the EU will be decided within the year. If it is found to be a public transport provider, rather than 'just' an internet platform the consequences for Uber (and many other new business models) will be major. Transport law is well developed and in the EU there is a strong set of protections for passengers. The costs could be high.

- If more and more courts determine that their drivers are employees, their costs and liabilities will increase considerably.

- If an argument is successfully mounted, especially within the EU that Uber is, in legal reality, an intermediary, much as Manpower, Adecco and Ranstadt are, in that they supply workers to clients/ passengers, Uber may well be subject to increased control and face the need to provide more protections for their drivers. Again, costs would inevitably rise.

\section{CONCLUSION}

The case of Uber is a fascinating one. It highlights so many contemporary business and legal issues, especially the fairly new developments in the ways in which services are delivered. There is no reason to 
suspect that these developments will not continue and even gather momentum. Many IPros who access work, deliver skills or who work on a cooperative or collaborative basis do so via internet platforms or other forms of intermediation. The controversies and uncertainties considered in the context of Uber may also face many of them.

For example, there are constant arguments about the employment status of IPros, with increasing efforts to provide a robust definition but none has yet been developed that does not depend to a greater or lesser extent on local or national conditions or culture. The concerns that many voice about the precariousness of self-employed Uber drivers, who cannot access a wide range of social protections can equally apply to IPros. The risks are considerable, especially in funding retirement and ill health, and surviving periods without work, so it is essential to take a longer view of people in the 'gig' economy, rather than a snapshot.

A critical issue for all in the 'gig' economy is not just the day-to-day risks of not having work, but the need to maintain skills levels, which for knowledge workers is essential in order to sustain their way of working. The data on training and up skilling by the self-employed is extremely worrying (Leighton, 2013). But, of course, it is rare for funded systems of training and lifelong learning to include access by the self-employed: they normally have to fund themselves.

Then there is the issue of income. The likely increased competition faced by individual Uber drivers, as there is no limit on the number of drivers, no requirement for registration and qualifications, will almost inevitably reduce incomes. The self-employed are already seeing decline vis à vis employees. IPros are in a stronger position as typically highly skilled. Nonetheless, those providing services for the public sector, in particular have seen incomes reducing (ONS, 2016). It is, of course, accepted that the key motivator for IPro working is only rarely money but without some form of protection many IPros, especially perhaps young ones, will not survive.

\section{THE LAST WORD HAS TO BE 'REGULATION': MAYBE WE HAVE TO ROLL BACK THE 'DEREGULATION MANTRA'?}

It is not hard to see some of the implications for IPros from the experience of Uber. The parallels are not precise but there some major areas of commonality. The self-employed regardless of skill level or work sector have been marginal in most developed economies until recently. Mostly, they got on with their work, be it as an accountant, farmer or shop keeper, usually delivering their services directly to clients or customers and usually in a limited geographical area. The internet, new ways of working, working across national borders has, of course, made dramatic changes. However, our regulatory framework has little changed and many of the 'old' issues, such as ambiguous employment status and many fiscal issues remain the same. The imperative of defining Uber itself is proving very difficult, not least because of the reluctance of many policy and law-makers to regulate and control businesses.

It is suggested that an urgent review be undertaken about regulation itself and its application to new forms of service delivery. For example, does regulation really add to costs? Do people comply with it? How important are enforcement mechanisms? Is there some type of regulation that people are more inclined to accept than others? Why? What is 'good' regulation and should not Impact Assessments go beyond simply looking at cost (Picciotto, 2002).

Following this, an attempt should be made to find the appropriate regulatory framework not just for Uber but importantly for IPros and other self-employed people. The Uber story is an important one, not least in focussing our minds on some core issues around responding to change, avoiding disputes through a sensible, balanced and clear regulatory framework so as to facilitate effective businesses and employment practices. 


\section{ACKNOWLEDGEMENTS}

The author thanks those who have read and commented on this article, especially Dr. Tui Mckeown and the members of the European Forum for Independent Professionals (EFIP) with whom the author has discussed many aspects of this article and the ideas within it. The author also thanks reviewers for their helpful comments.

\section{References}

Abbot, A. (1988). The system of professions: An essay on the division of expert labour. Chicago: University of Chicago Press. ABC News (2014). 27 January 2014.

Ackers, P. (2014). Re-thinking the employment relationship: A neopluralist critique of British industrial relations orthodoxy. International Journal of Human Resource Management, 25(2), 2608-2625.

Bridge, S. (2010). Rethinking enterprise policy: Can failure trigger new understanding. London: Palgrave Macmillan.

Burke, A. (2012). The role of freelancers in the 21st century British economy London. London: PCG.

Busby, N., \& Christie, D. (2005). The regulation of temporary agency work in the European Union. The Cambrian Law Review, 36, 15-28.

Campbell, D. (2010). Gathering the water: Abuse of rights after recognition of government failure. Journal of Jurisprudence, 7, 487-534.

Carbonaro, E. (Ed.) (2016). The technological revolution. Brussels: Socialists and Democrats.

Carr-Saunders, A., \& Wilson, P. (1933). The professions. Oxford: OUP.

Casale, G. (2012). The employment relationship: A comparative overview. Geneva: ILO.

Chokkattu, J. (2014). A brief history of Uber. Telecrunch, 14 August 2014.

Citizen Business (2016). Another Uber taxi torched. Citizen Business, March 23.

Cooper, D. (2006). Knowledge workers. Canadian Business, 73(2), 59-70.

Cooper, C., Mitchell, M., \& Thierer, A. (2014). The sharing economy and consumer protection regulation: the case for policy change. Mercatus Working Paper. Arlington: George Mason University.

de Flamingh, J., \& Cameron, A. (2015). Is it a duck or a rooster? The challenge of distinguishing between an employee and independent contractor in the new sharing economy. New South Wales: Law Society.

Dellot, B. (2013). Disrupt inc: How young people are challenging the convention of entrepreneurship. London: Royal Society of Arts.

Drexl, J., \& Di Porto, F (Eds.) (2015). Competition law and regulation. Cheltenham: Edward Elgar.

Dygryse, C. (2016). Digitalisation of the economy and its impact on the labour market (Working Paper No. 02). Brussels: ETUI.

European Commission (EC) (2012). Supporting entrepreneurs and the self-employed. Luxembourg: EC.

European Commission (EC) (2014). Action lines for liberal professions: Final report of the working group. Brussels: EC.

European Forum for Independent Professionals (EFIP) (2015). Developments in categorising and differentiating the employee from the professional self-employed: Reports from nine EU member states (Outcomes of EFIP meeting), Munich, November. Brussels: EFIP.

European Foundation (EF) (2014). New Forms of Work. Dublin: European Foundation.

EF (2015). New forms of employment. Dublin: European Foundation for the Improvement in Living and Working Conditions.

EF (2016). Digitalisation and working life: Lessons from the Uber cases around Europe. Dublin: The European Foundation for the Improvement of Living and Working Conditions.

European Parliament Magazine (2015). The commission launches study on UBER. European Parliament Magazine, Brussels, September 1 .

Forbes (2015). Juries to decide landmark cases against Uber. Forbes Magazine, March 11.

Friedman, G. (2014). Workers without employers, shadow corporations and the rise of the gig economy. Review of Keynesian Economics, 2, 171-188.

FT (2016). Uberisations and the danger of neo-serfdom, August 9 2016, Financial Times.

Genov, N. (2014). The future of individualisation in Europe. Changing configuration in employment governance in Pausch (ed.). The Future of Europe. Special Edition, European Journal of Futures Research, 2, 46-55.

Ghosh, S., \& Malloy, R. (2011). Creativity, law and entrepreneurship. Cheltenham: Edward Elgar.

Giddens, A. (1991). Modernity and self-identity: Self and society in the late modern age. Cambridge: Polity Press. 
Gratton, L. (2011). The shift: The future of work is already here. London: Collins.

Green, A., \& Barnes, S.-A. (2013). Crowdsourcing for paid work. Warwick: Institute for Employment Research.

The Guardian (2015). Why the world's biggest ride sharing company has no drivers. The Guardian, November 15.

Heery, E. (2005). Trade union responses to agency labour in Britain. Industrial Relations Journal, 35(3), 435-450.

Heery, E., Conley, H., Delbridge, R., \& Stewart, P. (2004). Beyond the enterprise: Trade union representation for freelancers in the UK. Human Resource Management Journal, 14(2), 20-35.

Heimans, J., \& Timms, H. (2014). Understanding new power: The crowd is challenging traditional leadership: here's how to harness the energy. Harvard Business Review, December, 50-56.

Hill, S. (2015). Raw deal: How the UBER economy and runaway capitalism are screwing American workers. New York: St Martin's Press.

Huws, U., \& Joyce, S. (2016). Crowd working survey, UK. Hatfield: University of Hertfordshire.

International Labour Office (ILO) (2016). World employment and social outlook 2016. Geneva: International Labour Ofiice.

Kenny, C. (2014). Disruptive innovation in the markets for legal services. Public Lecture, March 6, Harvard Law School, Harvard, MA, USA.

Kitching, J., \& Smallbone, D. (2012). Are freelancers a neglected form of small business? Journal of Small Business and Enterprise Development, 19, 74-83.

Leighton, P. (2011). 'Neither fish nor fowl: The professional self-employed and the need for a better regulatory framework' CESR review. Bristol: University of the West of England.

Leighton, P. (2013). Future working: The rise of Europe's independent professionals (With D. Brown) London: PCG.

Leighton, P. (2014). The rise of the independent professionals: But why the unwillingness to embrace them? Business Law Review (3), 84-92.

Leighton, P. (2015). Independent professionals: Legal issues and challenges. International Review of Entrepreneurship, 13(2), 81-92.

Leighton, P., \& Mckeown, T. (2015). The rise of independent professionals: The challenge for management. Small Enterprise Research, 22(2-3), 119-130.

Leighton, P., Syrett, M., Hecker, R., \& Holland, P. (2007). Out of the shadows: The management of self-employed, agency and outsourced workers. Oxford: Butterworth-Heinemann.

Leighton, P., \& Wynn, M. (2011). Classifying employment relationships: More sliding doors or a better regulatory framework? Industrial Law Journal, 40(1), 5-91.

Lewis, S. (1997). Family-friendly employment policies: A route to changing organisational culture or playing at the margins? Gender, Work and Organisation, 4(1), 13-24.

Marchington, M., Grimshaw, D., Rubery, J., \& Willmot, H. (2004). Fragmenting work, blurring boundaries and disordering hierarchies. Oxford: OUP.

McKeown, T. (2000). Why do professionals become contractors?. Melbourne: Monash University.

McKeown, T. (2009-2015). The IPRO index. Melbourne: Entity Solutions and Monash University.

Mettler, A., \& Williams, A. (2011). The rise of micro-multinationals: How freelancers and technology, savvy start-ups are driving growth, jobs and innovation. Brussels: Lisbon Council.

Muehlberger, U. (2007). Dependent self-employment. Basingstoke: Palgrave Macmillan.

NESTA (2015). The creative economy and the future of employment. London: NESTA.

Office of Tax Simplification (2015). Employment status review and outcomes. London: OTS.

ONS (2016). Office of National Statistics, Newport, Wales, UK.

Pelissie, M., \& du Rausas, M. (Eds.) (2015). Internet matters: The net's sweeping impact on growth, jobs and property. San Francisco, CA: McKinsey Global Institute.

Perlow, L., \& Kelly, E. (2014). Towards a model of work redesign for better work and a better life. Work and Occupation, 14(1), 111-134.

Picciotto, S. (2002). Reconceptualising regulation in an era of globalisation. Journal of Law and Society, 29(1), $1-11$.

Pofeld, E. (2016). How happy is your UBER driver: Survey offers a candid glimpse of gig economy workers. Forbes Magazine, February 7.

PriceWaterhouseCoopers (PWC) (2016). The future of work. London: PWC.

Rapelli, S. (2012). European IPros: A study. London: PCG. 
Reuters (2015). A test case for Uber's bold global push. Reuters News, October 5.

Richardson, I., Kakabdse, A., \& Kakabadse, N. (2011). Bilderberg people: Elitee power and consensus in world affairs. London: Routledge.

Roy Morgan (2016a). The Uber phenomenon. February 8, Roy Morgan Research.

Roy Morgan (2016b). Optus reaches out to 1 million UBER passengers. March 30, Roy Morgan Research.

Solicitors Regulatory Authority and the Legal Services Board (SRA/LSB) (2015). Innovation in legal services . London: SRA/LSB.

Spreitzer, G., Bacavice, P., \& Garrett, L. (2015). Why do people thrive in co-working spaces? Harvard Business Review, $28-30$.

Stone, K., \& Arthurs, H. (Eds.) (2013). Re-thinking workplace regulation: beyond the standard contract of employment. Russell: Sage Foundation.

Times of India (2014). Uber cab rape case. Times of India, December 12. 